\title{
Díaz Cintas, J. (Ed.) (2008). The didactics of audiovisual trans- lation. Amsterdam: John Benjamins. 263p.
}

The concept of interdisciplinarity has become part of contemporary mainstream academic research and has greatly contributed to a more multifaceted and enriched understanding of a variety of fields of research. However, with the concept of interdisciplinarity often come the risks of fragmentation and of trying to cover too many variables. Such risks loom especially when two or more fields of research interact to consolidate, reconceptualize and imprint past, present and future research. The field of audiovisual translation is no stranger to interdisciplinarity. As a distinct yet academically pliable field of research it uses insights from a multitude of other fields (e.g. linguistics, psychology, semiotics, technology) in an attempt to consolidate new findings both theoretically and practically. It is within the context of growing interdisciplinarity that Díaz Cintas's edited book The didactics of audiovisual translation and its accompanying CD-ROM can be read and used as a means of inspiration.

The clear link that Díaz Cintas tries to establish is the link between audiovisual translation on the one hand and the didactics of this highly unique form of translation on the other. With a total of 15 contributions divided into four distinct parts, Díaz Cintas and his contributors provide the reader with copious insights ranging from theory-related and conceptual information to practice-related exercises and materials for pedagogical interventions.

Part 1, entitled Inside $A V T$, sheds light on two areas which, according to Díaz Cintas, form the two prerequisites for any course on audiovisual translation: the semiotics of the audiovisual product and the importance of screenwriting in the training of audiovisual translators. In the first contribution (The nature of the audiovisual text and its parameters), Patrick Zabalbeascoa provides an analysis of the various constituent elements of audiovisual texts. Not only are the individual components of audiovisual texts described, but also the various intricate relationships between those components are highlighted. In so doing, Zabalbeascoa shows that the boundaries between the various components are not as clear-cut as one might expect and that areas of overlap can clearly be distinguished. In the second contribution (Screenwriting and translating screenplays), Patrick Catrysse and Yves Gambier turn the focus to screenwriting, which has become immensely popular but is nonetheless still largely ignored in AVT training programmes. The authors analyse screenwriting and highlight the various processes which can be found in screenwriting, all while making links to AVT. It is Catrysse and Gambier's view that insights into the various processes and strategies that professional screenwriters use can help improve the quality of both the translation process and the translated screenplay. In the third and final contribution in Part 1 (Screenwriting, scripted and unscripted language: What do subtitlers need to know?), Aline Remael investigates subtitles, which she describes as a highly special form of translation. 
Her analysis distinguishes between film dialogue and impromptu speech (both forms of spoken language) and discusses the specific features of these forms of spoken language with regard to the creation of subtitles. In addition, Remael also focuses on the importance of developing students' insight into screenplays (especially the dramatic composition of screenplays) when training future subtitlers.

Part 2, Hands-on experience in AVT, turns the focus to the actual practice of audiovisual translation. With a total of seven contributions it is the largest part of the volume. In the first contribution in this part (Subtitler training as part of a general training programme), Jan-Louis Kruger highlights the need for so-called general language practice training as a basic requirement for training in specialised fields of translation such as audiovisual translation. The focus on such a solid foundation in general language practice training should be the first step towards specialisation. Consequently, Kruger believes that such general language practice training should be the foundation on which a training programme moves from general to more specific training. In the second contribution (Teaching and learning to subtitle in an academic environment), Jorge Díaz Cintas turns the focus to subtitling and discusses the variety of considerations that must be taken into account for setting up a subtitling module. He does this by considering both theoretical and practical aspects and by providing what he refers to as a "hands-on approach" to subtitling. The third contribution (Learning to subtitle online: Learning environment, exercises, and evaluation), provided by Eduard Bartoll and Pilar Orero, brings the practice of subtitling into the realm of $21^{\text {st }}$-century didactics by considering the feature of online teaching and its growing popularity. In their discussion of an online module offered by the Universitat Autònoma de Barcelona they share with the reader various aspects of this new form of digital technology. The fourth contribution is Anna Matamala's chapter on voice-over (Teaching voice-over: A practical approach), in which she addresses yet another mode of audiovisual translation. Matamala not only discusses the features used in the Universitat Autònoma de Barcelona's MA module on voice-over, she also provides exercises designed to practise features of this lesser known and less frequently taught mode of audiovisual translation. The fifth contribution is Frederic Chaume's chapter on synchronisation (Teaching synchronisation in a dubbing course: Some didactic proposals). The sixth contribution (Training translators for the video game industry), by Miguel BernalMerino, addresses issues at play in what is called the game localisation industry. The lack of academic focus on the translation of video games drives Bernal-Merino to discuss the current state of affairs in both the video game industry and academia. In so doing, the author promotes interaction between the industry at hand and academics with the suggestion of a specialisation module within the field of translation studies dedicated to translation of multimedia interactive entertainment software. The seventh and final chapter in this part (Teaching audiovisual translation in a European context: An inter-university project) is Fernando Toda's contribution to a 
project for teaching audiovisual translation skills to students from five European countries by means of joint, intensive courses in the areas of subtitling, dubbing and voice-over.

Part 3, entitled $A V T$ for special needs, focuses on providing access to audiovisual media to people with sensory impairment. As such, it investigates two relatively new practices aimed at and providing such access: subtitling for the deaf and hard-of-hearing (SDH) and audio description (AD). The objective of this part is to highlight the practises of SDH and AD in an attempt to realise greater diffusion of the practices and, in so doing, to realise a reality in which truly everyone has access to audiovisual media. In the first contribution (Training in subtitling for the d/Deaf and the hard-ofhearing), Josélia Neves focuses on the specific features of SDH. Neves stresses the importance of considering these features when contemplating the set-up of SDH training programmes. SDH professionals are not only expected to have acquired general subtitling skills, but they are also required to master the skill of transferring messages intersemiotically, that is, from acoustic to visual codes. Insights into the specificity of this task will benefit any pedagogical considerations taken with reference to the practice of SDH. The second contribution (Audio description: The visual made verbal), provided by Joel Snyder, is similar to Neves's SDH contribution in that it also deals with pedagogical considerations, but this time the practice under investigation is that of audio description. Snyder takes a practiceinspired approach and outlines several ways in which AD may be presented, for example, in training programmes by means of a case study.

Part 4, AVT in language learning, moves the volume's focus to the potential of both intralingual and interlingual subtitles for facilitating both the foreign language learning process and the foreign language teaching process. In the first contribution in this part (Using subtitled video material for foreign language instruction), Jorge Díaz Cintas and Marco Fernández Cruz use the findings from various experiments designed to evaluate the role and impact of subtitled video material in the foreign language learning/teaching process. Díaz Cintas and Fernández Cruz's overall conclusion is that subtitled video material is indeed educationally beneficial in the foreign language learning/teaching process. However, they also point out that the use of subtitled video material is generally underweighted and advocate increased use of such material in the foreign language classroom. In the second contribution (Tailor-made interlingual subtitling as a means to enhance second language acquisition), Maria Pavesi and Elisa Perego flesh out the use and effects of subtitling in the foreign language process and consider a specific form of subtitles (SLA-oriented, interlingual subtitles) in what is referred to as incidental second language acquisition. The focus of this contribution is not on instructed second language acquisition but rather on uninstructed instances of second language acquisition and on creating subtitles for language learning purposes rather than on using subtitles to acquire foreign languages. The third and final contribution in this last part is by Vera Lúcia Santiago Araújo (The educational use of subtitled films in 
EFL teaching). Santiago Araújo's contribution presents the findings of an experimental longitudinal project on whether subtitled films help foreign language learners of English improve their oral proficiency and how such films do this.

Although the 15 contributions cover an exceptionally wide range of topics and could, at first glance, be viewed as a prime example of the fragmentation that interdisciplinarity may lead to, Díaz Cintas provides a clear overarching structure into which the 15 interrelated contributions should be placed. This structure consists of four complementary parts, structured as follows: Part 1, Inside AVT (3 contributions), Part 2, Hands-on experience in AVT (7 contributions), Part 3, AVT for special needs (2 contributions) and Part 4, AVT in language learning (3 contributions). In turn, the four parts are nested within an overall structure that seeks to introduce and contextualize various didactic approaches to teaching (audiovisual) translation. What is new about Díaz Cintas's edited volume is its focus on both audiovisual translation (as a unique form of translation) and audiovisual translation training in all of its individual components. Díaz Cintas describes the goal of this volume as follows: "This selective compilation of 15 studies constitutes a rounded vision of the many different ways in which audiovisual programmes are translated and made accessible in different countries. By approaching them from a pedagogical perspective, it is hoped that this complex and dynamic area in the translation discipline, seen by many as the quintessence of translation activity in the twenty-first century, will make a firm entry into university curricula and occupy the space that is deserves in academia" (p. 18). Díaz Cintas's collection of contributions on the didactics of audiovisual translation shows unequivocally that interdisciplinarity need not lead to fragmentation. In addition, Díaz Cintas's edited volume demonstrates that interdisciplinarity that has been contextualised in a carefully considered overall structure can lead to productive insights that benefit the conceptual foundation of the discipline of audiovisual translations as well as those involved in the process of audiovisual translation training.

Jimmy Ureel - Department of Translators and Interpreters, Artesis University College, Antwerp

\section{Ferreira Duarte, J., Alexandra Assis Rosa, \& Teresa Seruya (Eds.) (2006). Translation studies at the interface of disciplines. Amsterdam/Philadelphia: John Benjamins. 207 p.}

Translation Studies at the Interface of Disciplines est le fruit d'une conférence tenue à la Faculté de Lettres de 1'Université de Lisbonne en novembre 2002 et intitulée Translation (Studies) : A Crossroads of Disciplines. L'ouvrage, qui entend participer au processus d'introspection dans 